\title{
Effect of Service Quality Toward Student Satisfaction and Loyalty in Higher Education
}

\author{
Hardi MULYONO ${ }^{1}$, Arief HADIAN², Nelvitia PURBA ${ }^{3}$, Rudy PRAMONO ${ }^{4}$
}

Received: August 01, 2020 Revised: September 06, 2020 Accepted: September 12, 2020

\begin{abstract}
This study analyzes the effect of quality of services provided to the students' in relation to their satisfaction and loyalty. Respondents in this study were seventh semester students of Universitas Muslim Nusantara Al-Washliyah, the total number of students was 312 . Data analysis techniques in this study used was SEM (Structural Equation Modeling) using the SmartPLS program. The results showed that students' satisfaction significantly mediated the correlation between academics and students' loyalty, between non-academic and students' loyalty, between reputation and students' loyalty, and between campus access and students' loyalty; on the other hand, students' satisfaction was not significant in mediating the correlation between program issues and students' loyalty. The findings suggest that it is necessary to improve the quality of lecturers to improve students' academic abilities and communication skills. As far as non-academic aspects are concerned, conducting training and development efforts and increasing awareness programs for administrative staff is important. For the reputation aspect, to carry out several marketing campaigns which predict to have an effect upon students in building positive perceptions of campus has to be executed as well. Meanwhile for access aspect, it should be made certain that every student can have direct access to staff employees, and it is necessary to improve dimensions which can increase students' satisfaction so that students are convinced of their choice of campus and then they are likely to recommend their chosen university and spread positive things about their institutions.
\end{abstract}

Keywords: Service Quality, HedPERF, Student Satisfaction, Student Loyalty, University Student

JEL Classification Code: E44, F31, F37, G15

\section{Introduction}

At present, the competition among private universities is so high, that students' satisfaction has to be prioritized by the universities. Attracting new students and retaining existing students has become an urgent and important goal for many

${ }^{1}$ First Author. Universitas Muslim Nusantara AI Washliyah, Indonesia. Email: hardimulyono@umnaw.ac.id

${ }^{2}$ Universitas Muslim Nusantara AI Washliyah, Indonesia.

Email: ariefhadian@umnaw.ac.id

${ }^{3}$ Universitas Muslim Nusantara AI Washliyah, Indonesia.

Email: nelvitiapurba@umnaw.ac.id

${ }^{4}$ Corresponding Author. Lecturer, Pelita Harapan University, Indonesia [Postal Address: MH Thamrin Boulevard 1100, Klp. Dua,

Kec. Klp. Dua, Tangerang, Banten 15811, Indonesia]

Email: rudy.pramono@uph.edu

(c) Copyright: The Author(s)

This is an Open Access article distributed under the terms of the Creative Commons Attribution Non-Commercial License (https://creativecommons.org/licenses/by-nc/4.0/) which permits unrestricted non-commercial use, distribution, and reproduction in any medium, provided the original work is properly cited. existing higher education institutions (Angell, Heffernan, \& Megicks, 2008). Therefore a higher education institution, which aims at gaining a competitive advantage in the future, needs to find an effective and creative way to attract, maintain and foster stronger relationships with students (Hasan, Ilias, Rahman, \& Razak, 2008).

For this reason Universities as academic institutions should continue to innovate, diversify their structures and find new ways to provide their services more effectively to their customers (Rain, Sinha, \& Sahney, 2011; Rahman et al, 2020). The occurrence of this phenomenon was challenging the Universities to provide the best service to students in order to win the competition. As the market have become more competitive for universities, Universitas Musim Nusantara Al-Washliyah as a private university in Medan has kept on improving the quality of services provided to the students so that it can maintain students' satisfaction and loyalty. Quality of service has a big role for various institutions as a way of maintaining the number of students by capturing the education market (Yeo, 2008). Providing the best service is a key to success in surviving the competition (Zeithaml, 
Berry, \& Parasuraman, 1996, Nguyen at al, 2020, Tabash et al, 2019). Even great Universities in Asia are striving to achieve student satisfaction and loyalty, by researching on quality issues and maintaining the existing and expected quality of services (Yeo \& Li, 2014).

In an effort to improve the quality of services, there are deficiencies that should be corrected. Preliminary surveys conducted shows that there are several deficiencies, namely the lack of lecturers in mastering teaching materials, lack of lecturers who can communicate well while teaching, lecturers who do not care about students, campuses that are still being collaborated and are less professional, learning facilities and infrastructure that are still in poor condition, lecture rooms that are less conducive to lectures, and poor administrative staff services for the students. Considering this condition, it is necessary to find out the quality of services provided in Universitas Muslim Nusantara Al-Washliyah. The institution quality was based on understanding students' perceptions by using quality measurements of the HedPERF scale, which is a scale for measuring service quality based on students' perceptions of college performance (Abdullah, 2006a). The HedPERF scale consisted of several dimensions including academic aspects, non-academic aspects, program issues, reputation and access. The HedPERF quality measurement scale has the best capability in measuring aspects of Brochado higher education (2009) and the best capability in measuring higher education (Ali, Zhou, Hussain, Nair, \& Ragavan, 2016).

Knowing the perception of the quality of services provided by Universitas Muslim Nusantara would give an overview of the real condition of students' satisfaction and loyalty. If businesses (universities) understand the reality and make efforts for giving satisfaction to the customers (students) then it will be beneficial for the businesses (universities) in the long run as it will help them gain an additional market share which will result in greater profitability. (Anderson, Fornell, \& Lehmann, 1994). Arambewela \& Hall (2009) state that student satisfaction is one of the main goals of tertiary institutions, because satisfied students make a source of competitive advantage that results in positive word of mouth/oral communication (direct spoken promotion) and helps in students' retention and loyalty.

According to Abdullah (2006) Students' satisfaction plays an important role in university success and can act as an important tool in improving perceived service quality. Thus students are increasingly seen as consumers of higher education services, for that satisfaction becomes a very important aspect for educational institutions in recruiting new students (Thomas \& Galambo, 2004). It is the responsibility of higher education institutions to understand the process of creating students' satisfaction, and also to find ways and means that can be relied upon to measure satisfaction (Alves \& Raposo, 2009). Therefore students' satisfaction and loyalty is the most important keys to determine the most appropriate strategic management to ensure successful long- term performance for public and private institutions (Yusof, Zaini, \& Mansor, 2019).

The previous study was done by Ali et al. (2016) that the five dimensions of HedPERF affect students' satisfaction, and it turn it affect students' loyalty. But the study conducted by Arrivabene, Vieira, and Mattoso (2019) that academic aspects, program issues and reputation have a significant effect on students' satisfaction but non-academic aspects and access aspects have no effect on satisfaction, whereas overall service quality has an effect on students' satisfaction and in turn students' satisfaction has an effect on students' loyalty. But in the research conducted by Iswara and Pratomo (2018) that apart from the academic aspect, non academic aspects and reputation aspects also significantly affects students' satisfaction, while aspect of program problems and access aspects did not affect students' satisfaction, and as a result it did not affect students' loyalty. There are some hypotheses on this study, namely:

H1. Academic aspects have a positive effect on students' satisfaction

H2. Non-academic aspects have a positive effect on students'satisfaction

H3. Reputation has a positive effect on students' satisfaction

H4. Access has a positive effect on students'satisfaction

H5. Program issues have a positive effect on students' satisfaction

H6. Students' satisfaction affect students' loyalty.

\section{Research Method}

This study was conducted in Universitas Muslim Nusantara Al-Washliyah Medan, from November 2019 to December 2019. This research method was carried out using quantitative research using Smart PLS analysis tools. The population of this study was $7^{\text {th }}$ semester students who were active students of the Universitas Muslim Nusantara Al-Washliyah; the total number of students was 1619 . The consideration for taking the students as the population used, because students in this semester had more experience in studying at Universitas Muslim Nusantara Al-Washliyah. The sample in this study was obtained using the Slovin formula with an error rate of 5\%, a sample of 321 students was obtained. The sampling technique used perposive random sampling technique which was distributed in 6 faculties and 14 majors. Analysis of the data of this study used Structural Equation Modeling (SEM) with software Smart Partial Least Squares (SmartPLS). The evaluation of the PLS model was done by evaluating outer model and then the inner model. Outer model is a measurement model to predict the correlation between indicators or parameters estimated with their latent variables, meanwhile inner model is a structural model for predicting causality between latent variables. 
This research instrument consisted of three variables, the first variable is the service quality variables with models HERPERF, adapted from Abdullah (2006a), it consisted of five dimensions, namely academic aspects (nine items), nonacademic aspects (twelve items), reputation (nine items), access (eight items) and finally program issues (two items), all of these together consists of forty items. One item was not included in this model and that is the boarding item just beause of the fact that there was no boarding house in this institution. The second variable is the students' satisfaction which was adapted from Ali et al. (2016) and it consisted of five items. The third variable is students' loyalty which was adopted from Mohamad and Awang (2009) and it consisted of four items. For the distribution of questionnaires a five-liket scale was used.

\section{Research Results}

\subsection{Evaluation of Measurement Model (Outer Model)}

The reliability test for the indicators in the PLS was assessed based on the value of the loading factors indicator that measured the construct. An indicator can be declared valid if the loading factor value is above 0.5. According to Hair, Hult, Ringle, and Sarstedt (2017), an outer loading value between $0.5-0.6$ is considered sufficient to meet the requirements for convergent validity. This convergent validity assessment is done by looking at the average variance extracted (AVE) value in each existing construct. Hair et al. (2017) state that the AVE value for each good construct should be $>0.5$. Internal consistency reliability assessments are performed on each construct. The value of compatibility of each construct is expected to be at least 0.7 . However, in exploratory research the value of composite reliability $\geq 0.6$ is acceptable (Sekaran \& Bougie, 2016).

Considering the results in Table 1, it was revealed that each of many research variable indicators has an outer loading value $>0.5$. The data showed that the indicator can be concluded as feasible or valid and can be used for research and further analysis. The value of composite reliability indicated that the good enough category of each construct has met the criteria with a composite reliability value $>0.7$. The analysis of the outer model can proceed to the outer validity of the model. The AVE value of each construct in the final model has reached $>0.5$. Thus, the structural equation model proposed meets the criteria of convergent validity (see Table 1).

Table 1: Validity dan Reliability

\begin{tabular}{|c|c|c|c|}
\hline Dimension/variable & Loading factor & AVE & CR \\
\hline \multicolumn{4}{|l|}{ ACADEMIC } \\
\hline Lecturers have knowledge in the material being taught & 0.821 & 0.600 & 0.931 \\
\hline Lecturers care and polite to their students & 0.831 & & \\
\hline Lecturers respond to requests for help from students & 0.709 & & \\
\hline Lecturers are sincerely interested in solving students' problems & 0.752 & & \\
\hline The lecturer shows a positive attitude towards students & 0.745 & & \\
\hline Lecturers communicate well in the classroom & 0.782 & & \\
\hline Lecturers give attention about student progress & 0.786 & & \\
\hline Lecturers provide adequate and comfortable time in consultation & 0.771 & & \\
\hline Educated lecturers and experience in teaching & 0.768 & & \\
\hline \multicolumn{4}{|l|}{ NON ACADEMIC } \\
\hline Administrative staff are sincerely interested in solving student problems & 0.824 & 0.640 & 0.955 \\
\hline Administrative staff pay attention individually to students & 0.709 & & \\
\hline Administrative staff handle complaints and inquiries quickly and efficiently & 0.772 & & \\
\hline Administrative staff immediately responded to student requests for help & 0.833 & & \\
\hline Administrative staff keep accurate and easily accessed data & 0.797 & & \\
\hline Administrative staff perform services as promised & 0.839 & & \\
\hline Administrative staff carry out operational services appropriately and comfortably & 0.860 & & \\
\hline
\end{tabular}


Table 1: Continued

\begin{tabular}{|c|c|c|c|}
\hline Administrative staff showed a positive work attitude towards students & 0.806 & & \\
\hline Administrative staff in working to communicate well with students & 0.852 & & \\
\hline Administrative staff have knowledge of administrative procedures & 0.749 & & \\
\hline Students feel comfortable and trust in the services provided by the campus & 0.781 & & \\
\hline The campus provides reasonable service time & 0.769 & & \\
\hline \multicolumn{4}{|l|}{ REPUTATION } \\
\hline The campus has a professional image & 0.715 & 0.583 & 0.926 \\
\hline The campus has adequate academic facilities (classrooms, libraries, laboratories) & 0.745 & & \\
\hline The campus runs an internal quality assurance program well & 0.761 & & \\
\hline The campus has adequate discussion area facilities & 0.805 & & \\
\hline The size of the study room is minimal so interaction between students occurs & 0.761 & & \\
\hline Ideal location and appearance or campus layout & 0.767 & & \\
\hline The campus has majors that are well accredited & 0.737 & & \\
\hline Graduates are not difficult to get a job & 0.792 & & \\
\hline The campus has adequate health services & 0.787 & & \\
\hline \multicolumn{4}{|l|}{ ACCESS } \\
\hline The campus gives equal treatment and appreciation to all students & 0.762 & 0.627 & 0.931 \\
\hline The campus gives equal treatment and appreciation to all students & 0.836 & & \\
\hline The campus maintains the confidentiality of information provided by students & 0.778 & & \\
\hline Campus employees are easily contacted by telephone and other communications & 0.792 & & \\
\hline The campus provides adequate complaints services & 0.740 & & \\
\hline The campus supports student activities & 0.799 & & \\
\hline Campus responds to student complaints in improving service performance & 0.821 & & \\
\hline Service procedures provided by the campus are simple and easy & 0.804 & & \\
\hline \multicolumn{4}{|l|}{ PROGRAM ISSUES } \\
\hline The campus offers a variety of different majors & 0.904 & 0.788 & 0.882 \\
\hline Campus offers flexible programs (morning, afternoon and evening) & 0.872 & & \\
\hline \multicolumn{4}{|l|}{ SATISFACTION } \\
\hline I am satisfied with my decision to register on this campus & 0.860 & 0.763 & 0.942 \\
\hline My choice to choose this campus is right & 0.858 & & \\
\hline I think that my choice was right to choose to study at this campus & 0.909 & & \\
\hline My experience is very pleasant on this campus overall & 0.848 & & \\
\hline Overall, I am satisfied to study at this campus & 0.892 & & \\
\hline \multicolumn{4}{|l|}{ LOYALTY } \\
\hline Overall, I am satisfied to study at this campus & 0.660 & 0.686 & 0.896 \\
\hline I will continue my program at this Campus if in the department I choose & 0.815 & & \\
\hline I will give everyone good information about this campus & 0.905 & & \\
\hline I will always invite other people to join in college on this campus & 0.908 & & \\
\hline
\end{tabular}




\subsection{Evaluation of Structural Model (Inner Model)}

After the estimated model satisfied the Outer Model criteria, then the measurement was done by testing the structural model (Inner Model) by looking at the value of R-Square (R2) on the variable. The results of the R-Square (R2) values on variables based on the measurement results are shown in the following table (see Table 2).

Based on the data in Table 2, it can be observed that the R Square value for the Students' Satisfaction variable was 0.625 . This figure shows the percentage affected by the Academic variable. The effect of dimensions like Campus Access, Program Issues, Non Academic and Reputation on Students' Satisfaction was $62.5 \%$ while the remaining $37.5 \%$ was explained by other variables which was not examined in this study and the R Square Value for Students' Loyalty variables was 0.720 , which reveals that there is a lot of effect of Academic variable. The effect of dimensions like Campus Access, Program Issues, Non Academic, and Reputation on Student Loyalty was $65.2 \%$ while the remaining $34.8 \%$ can be explained by other variables which was not a part of this study.

\subsection{Direct Effect Test}

Hypothesis testing was done by T-statistics ( $\mathrm{t}$-test) with a significance level of 5\%. It was considered significanct if in this test $\mathrm{p}$-value $<0.05(\alpha 5 \%)$ was obtained, it meant that the test was significant, and vice versa if $p$-value $>0.05(\alpha 5 \%)$, which meant that it was not significant. The direct effect of test results of each variable could be seen in the SmartPLS algorithm Results Table in assessing the path coefficient directly given in Figure 1 and Table 3.

Table 2: R Square

\begin{tabular}{|l|c|c|}
\hline & R Square & R Square Adjusted \\
\hline Students' Satisfaction & 0.625 & 0.620 \\
\hline Students' Loyalty & 0.652 & 0.651 \\
\hline
\end{tabular}

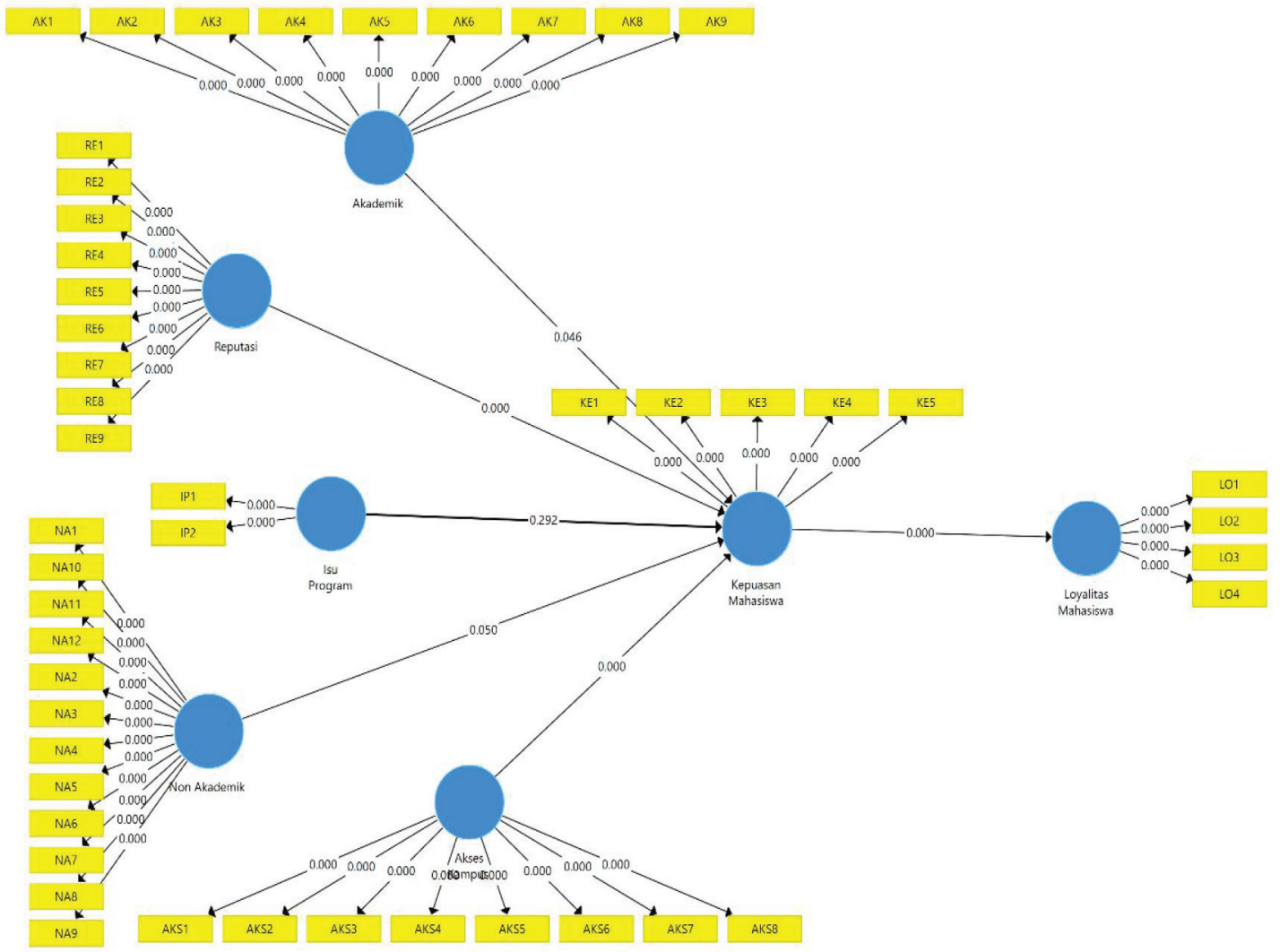

Figure 1: Structural model 
It can be seen from the results obtained in table 3 that as a result of testing the hypothesis, the coefficient of the academic aspect is 0.088 , which means that the academic aspect has a positive effect on students' satisfaction. A significance value of $\mathrm{p}$ with values $0.046<0.05$ was significant, therefore it was concluded that the academic aspect has a positive and significant effect on students' satisfaction. The coefficient of non-academic aspects was known to be 0.174 , therefore non-academic aspects have a positive effect on students' satisfaction and a significant value of $\mathrm{p}$ with values 0.050 $<0.05$ was significant, therefore it was concluded that nonacademic aspects have a positive and significant effect on Students'satisfaction.

The coefficient value of the reputation aspect was known to be 0.236 , therefore the aspect of reputation had a positive effect on students' satisfaction and a significant value of $p$ with values $0,000<0.05$ was significant, From this it can be concluded that the reputation aspect had a positive and significant effect on students' satisfaction. The coefficient value of the access aspect was 0.396 , therefore the access aspect had a positive effect on students' satisfaction and a significant value of $p$ with value $0,000<0.05$ was significant, therefore it was concluded that the access aspect had a positive and significant effect on students' satisfaction. The coefficient value of the program issue was -0.037 , therefore the program issue had a negative effect on students' satisfaction and a significant value of $\mathrm{p}$ with values $0.22>$ 0.05 was not significant, therefore it was concluded that the issue of the program had a negative and did not have a significant effect on satisfaction of college students. When the coefficient of students' satisfaction was 0.807 , then the students' satisfaction had a positive effect on students' loyalty and a significant value of $p$ with value $0,000<0.05$ was significant. Therefore, it was concluded that students' satisfaction had a positive and significant effect on students' loyalty.

\subsection{Indirect Effect Test}

Indirect effect testing was also carried out by the T-statistics test (t-test), which had a significance level of 5\%, if the test got $p$-value $<0.05(\alpha 5 \%)$, then it meant that the test was significant and vice versa if p-value $>0.05(\alpha 5 \%)$ which meant that the test was not significant. The indirect test results of the analyzed latent variables can be seen in the Table 4 below:

It can be seen from the results obtained in Table 3 that the indirect effect of Academic variable on Students' Loyalty and Students' Satisfaction was 0.071, when the p-value is $0.047<0.005$, then the Academic variable indirectly and significantly affected the Students' Loyalty which was a result of Students'Satisfaction. In other words, Students'Satisfaction significantly mediated the correlation between Academics and Students' Loyalty. The indirect effect of Non Academic variables on Students' Loyalty through Students' Satisfaction was 0.141 , with a p-value of $0.049<0.005$. It meant that Non Academic variable had an indirect and significanct effect on Students' Loyalty through Students' Satisfaction.

Table 3: Path Coefficients

\begin{tabular}{|l|c|c|}
\hline & Original Sample (0) & P Values \\
\hline Academik -> Students' Satisfaction & 0.088 & 0.046 \\
\hline Non Academic -> Students, Satisfaction & 0.174 & 0.050 \\
\hline Reputastion-> Students_Satisfaction & 0.236 & 0.000 \\
\hline Access_Campus -> Students' Satisfaction & 0.396 & 0.000 \\
\hline Program Issue -> Students_Satisfaction & -0.037 & 0.292 \\
\hline Students_Satisfaction -> Students_Loyalty & 0.807 & 0.000 \\
\hline
\end{tabular}

Table 4: Indirect effect

\begin{tabular}{|l|c|c|}
\hline & Original Sample (0) & P Values \\
\hline Academic -> Students_Satisfaction-> Loyality_Students & 0.071 & 0.047 \\
\hline Non Academic-> Students_Satisfactiom -> Students_Loyalty & 0.141 & 0.049 \\
\hline Reputation -> Students_Satisfaction -> Students_Loyalty & 0.191 & 0.000 \\
\hline Campus_Access -> Students_Satisfaction -> Students_Loyalty & 0.320 & 0.000 \\
\hline Program_Issue -> Students_Satisfaction -> Students_Loyalty & -0.030 & 0.292 \\
\hline
\end{tabular}


In other words, Students' Satisfaction significantly mediated the correlation between Non-Academic variables and Students' Loyalty. The indirect effect of Reputation on Students' Loyalty through Students' Satisfaction was 0.191, with a p-value of $0,000<0.005$, so reputation was not directly having a significant effect on Students' Loyalty through Students' Satisfaction. In other words, Students' Satisfaction significantly mediated the correlation between Reputation and Students' Loyalty.

The indirect effect of Campus Access on Students' Loyalty through Students' Satisfaction was 0.320, with a p-value of $0,000<0.005$, the result showed that the Campus Access indirectly and significantly affected Students' Loyalty through Students' Satisfaction. In other words, Students' Satisfaction significantly mediated the correlation between Campus Access and Students' Loyalty. If the indirect effect of Program Issues on Students' Loyalty through Students' Satisfaction was -0.030 , with a $p$-value of $0.292>0.005$, then Program Issues indirectly have an insignificant effect on Students' Loyalty through Students' Satisfaction. In other words, Students' Satisfaction was not significant in mediating the correlation between Program Issues and Students' Loyalty.

\subsection{The Result of Measurement Model Test}

Based on the results of hypothesis testing conducted in testing the dimensions of service quality perception, the following variables which are academic aspects, nonacademic aspects, reputation aspects and access aspects, have a positive and significant effect on students' satisfaction. Meanwhile, One of dimension did not have significant effect on students' satisfaction which was program issues. Students with a favorable perception of service quality in terms of aspects like academic, non-academic, programs, reputation and access have a positive effect on their level of satisfaction and students were more loyal to the university. It showed that a high level of students' satisfaction can increase students' loyalty (Ali et al., 2016).

Based on the results of this study, on the dimensions of service quality perception, Access aspect and the Reputation aspect have the highest value. (Abdullah, 2005; Ali et al., 2016). The lowest variable in this study that affected students' satisfaction was the non-academic aspects, while the fifth hypothesis was that aspects of program issues did not affect students' satisfaction, this was in line with research (Damaris, Surip, and Setyadi, 2019; Iswara and Pratomo, 2018 ; Muhammad, Kakakhel, and Shah, 2018; Uddin and Ali, 2018). The last hypothesis was the variable of students' satisfaction which had a positive and significant effect on students' loyalty, this was in line with research (Ali et al., 2016; Arrivabene et al., 2019 Chandra, Hafni, Chandra, Purwati, and Chandra, 2019).
The results of the first hypothesis testing found that the dimensions of academic aspects have a positive and significant effect on student satisfaction. The first hypothesis testing is in line with research (Ali et al., 2016; Arrivabene et al., 2019; Iswara and Pratomo, 2018), that the dimensions of academic aspects have a positive and significant effect on students' satisfaction. The results of this hypothesis indicated that the better dimensions of academic aspects such as understanding of teaching material in class and level of education as well as the experience of lecturers, contributes to increased students' satisfaction. This result shows that the students prefer a lecturer who has a command over the subject while teaching in the class, apart from this the students expect that the lecturers should have adequate level of education and teaching experience as a lecturer. Other things that can increase students' satisfaction were lecturer's communication skills in the class and care for the students. This shows that students really want lecturers who are able to communicate well and have concern for the conditions and problems of students. For this reason, it is necessary for lecturers to improve academic abilities and communication skills as well as foster empathy for student problems (Arrivabene et al., 2019). Latif, Sahibzada, and Ullah (2017) emphasize that it is important for lecturers to deliver quality material in the classroom to students. Recruitment, selection and training carried out in increasing lecturer empathy towards students are important to the level of quality felt by students. It is an important aspect in the efforts made by the higher education institutions to become successful (CalvoPorral, Levy-Mangin, and Novo-Corti, 2013).

The results of the second hypothesis testing was that the dimensions of non-academic aspects had a positive and significant effect on students' satisfaction. The second hypothesis testing is in line with research (Ali et al., 2016; Iswara and Pratomo, 2018; Ushantha and Kumara, 2016). The results of this hypothesis indicated that the institution of higher education such as a Univerity, which has better non-academic aspects such as the ability of administrative staff to store students' data and which can be easily retrieved by the students significantly affected the level of students' satisfaction, this condition showed that students were very happy with the ability of administrative staff in storing students' data and making it available to students when they wanted to access it. Another thing that helps in increasing students' satisfaction was always keeping promises and always giving quick and efficientl responses when handling students' complaints. For the above reasons, training and development efforts as well as increasing awareness programs for administrative staff is very important in promoting the skills needed to increase effectiveness and efficiency in maintaining records, communication, changing attitudes and services to students (Ushantha and Kumara, 2016). 
The results of testing the third hypothesis found that the dimensions of the reputation aspects have a positive and significant effect on students' satisfaction. The third hypothesis testing is in line with research (Ali et al., 2016; Arrivabene et al., 2019; Iswara and Pratomo, 2018). The results of this hypothesis indicated that better aspects of reputation such as a professionally managed campus will increase students' satisfaction, this shows that students pay a lot of attention towards a professionally managed campus so the universities should give a lot of focus and attention towards campus image and should try to continue improving the image of a professional campus. Another thing that can increase students' satisfaction as a support to enhance campus reputation is the accreditation of all departments managed by the campus, through improvement in the marks and quality of existing departments' accreditation will lead to an increase in students' satisfaction. In addition, a campus that has good academic facilities, a good internal quality assurance program, adequate discussion areas, and all alumnus getting jobs easily will lead to an increase in students' satisfaction. Reputation building can be done by marketing campaigns and creating more awareness among students for supporting improvement in the campus image (Ali et al., 2016). By providing good service support to library services, computer and technology services, career consulting services, and learning support services will result in students having a positive perception of the campus (Calvo-Porral et al., 2013).

The results of the fourth hypothesis test was the dimensions of access aspect which had a positive and significant effect on students' satisfaction. The fourth hypothesis testing was in line with research (Ali et al., 2016; Damaris et al., 2019; Ushantha and Kumara, 2016). The results of this hypothesis indicated that the better aspects of access such as the campus supporting students activities would increase students' satisfaction. Other aspects that could help in increasing student's satisfaction was to maintain the confidentiality of information provided by students, campus employees who can be easily contacted, campuses who provide similar treatment to all their students. It is necessary to ensure that every student has direct access to staff employees such a their e-mail, telephone number as well as a physical meeting can greatly improve the Access aspect (Ali et al., 2016). Utilizing newer technologies and developing a culture of learning in a higher education institution would be good in increasing the dimensions of access (Ushantha and Kumara, 2016).

The results of the fifth hypothesis testing found that the dimensions of aspects of the program issues did not affect students' satisfaction. The fifth hypothesis testing was in line with research (Iswara and Pratomo, 2018; Muhammad et al., 2018; Uddin and Ali, 2018). The results of the hypothesis shows that the activities of a program issue have no effect.
Some facilities offered by the campus such as offering varying majors, flexible admission programs (morning, afternoon and evening) did not have an effect on students' satisfaction, this was due to the fact that students considered these features as a normal and regular facility and not a special feature. Regular facilities offered by the universities had no effect students' satisfaction.

The results of the sixth hypothesis testing was that the satisfaction variable has a positive and significant effect on students' loyalty. Testing these hypotheses is in line with research (Ali et al., 2016; Arrivabene et al., 2019). The results of this hypothesis indicated that by increasing students' satisfaction such as feeling satisfied by registering on this campus, feeling satisfied when they registered, and feeling satisfied with the lecture experience will significantly increase students' loyalty as well as increase commitment to continue their education there till they graduate. Positive word of mouth about the campus will lead to increase in admissions and students will continue to pursue higher degrees from the campus. As stated by Lukić and Lukić (2018) students' satisfaction can be seen in the fact that they recommend their chosen university to others. If the campus management has the knowledge about the dimensions of value for service quality then it can help them in allocating appropriate capital and human resources to provide a high level of service quality. (Paul dan Pradhan, 2019).

\section{Conclusion}

Based on the results of hypothesis testing, it can be concluded that academic aspects, non-academic aspects, reputation aspects and access aspects have significant effect on students' satisfaction and student satisfaction has an effect on students' loyalty in Universitas Muslim Nusantara Al-Washliyah. As for testing hypotheses on aspects of the program, it has no effect on student satisfaction at Universitas Muslim Nusantara Al-Washliyah. The next research agenda is that research needs to be done by expanding the variables that affect students' satisfaction and loyalty, and conducting research by expanding the area of research by conducting research at onother Universities owned by Al-Washliyah.

For the academic aspect it is necessary to improve the quality of lecturers in their academic abilities and communication skills, as well as provide quality material and continue to update the material taught in class, recruitment, selection and training to lecturers in an effort to foster lecturers' empathy towards students. For non-academic aspects, it is necessary to conduct training and development efforts and increase awareness programs for administrative staff on the need to increase effectiveness and efficiency in maintaining records, communication, changing attitudes, and services to students. For the reputation aspect, it is necessary 
to carry out several marketing campaigns by building more awareness to students about the positive perception of the campus, then to continue providing support services to library services, computer and technology services, career consulting services, and learning support services which are predicted for affecting students in building positive perceptions of campus.

Meanwhile for access aspect, certainty that every student can have direct access to staff employees such as e-mail, telephone and even meet directly is a step to improve access aspects, use of newer technologies and developing a culture of learning in an institution of higher education will be good in increasing the dimensions of access. For the satisfaction aspect, it is necessary to improve dimensions which can increase students' satisfaction so that students will be positively convinced of their choice of campus and then will recommend their chosen university and spread positive things by word of mouth to others, and allocate capital and the right human resources in providing a higher quality service at the university.

\section{References}

Abdullah, F. (2005). HEdPERF versus SERVPERF: The quest for ideal measuring instrument of service quality in higher education sector. Quality assurance in Education, 13(4), 305328. http://doi.org/10.1108/09684880510626584

Abdullah, F. (2006). The development of HEdPERF: A new measuring instrument of service quality for the higher education sector. International Journal of Consumer Studies, 30(6), 569581. http://doi.org/10.1111/j.1470-6431.2005.00480.x

Abdullah, F. (2006). Measuring service quality in higher education: HEdPERF versus SERVPERF. Marketing Intelligence \& Planning, 24(1), 31-47. http://doi.org/10.1108/02634500610641543

Ali, F., Zhou, Y., Hussain, K., Nair, P. K., \& Ragavan, N. A. (2016). Does higher education service quality affect student satisfaction, image and loyalty? A study of international students in Malaysian public universities. Quality assurance in Education, 24(1), 7094. http://doi.org/10.1108/QAE-02-2014-0008

Alves, H., \& Raposo, M. (2009). The measurement of the construct satisfaction in higher education. The Service Industries Journal, 29(2), 203 - 218. http://doi. org/10.1080/02642060802294995

Anderson, E. W., Fornell, C., \& Lehmann, D. R. (1994). Customer Satisfaction, Market Share, and Profitability: Findings From Sweden. Journal of Marketing, 58(3), 53-66. http://doi. org/10.1177/002224299405800304

Angell, R. J., Heffernan, T. W., \& Megicks, P. (2008). Service quality in post graduate education. Quality Assurance in Education, 16(3), 236-254. http://doi.org/10.1108/09684880810886259

Arambewela, R., \& Hall, J. (2009). An empirical model of international student satisfaction. Asia Pacific Journal of Marketing and Logistics, 21(4), 555-569. http://doi. org/10.1108/13555850910997599

Arrivabene, L. S., Vieira, P. R. D. C., \& Mattoso, C. L. D. (2019). Impact of Service Quality, Satisfaction and Corporate Image on Loyalty: A Study of a Publicly Traded for-Profit University. Services Marketing Quarterly, 40(3), 189-205. http://doi.org/1 $0.1080 / 15332969.2019 .1630174$

Brochado, A. (2009). Comparing alternative instruments to measure service quality in higher education. Quality assurance in Education, 17(2), 174-190. http://doi. org/10.1108/09684889510093497

Calvo-Porral, C., Levy-Mangin, J.-P., \& Novo-Corti, I. (2013). Perceived quality in higher education: An empirical study. Marketing Intelligence \& Planning, 31(6), 601-619. http://doi. org/10.1108/MIP-11-2012-0136

Chandra, T., Hafni, L., Chandra, S., Purwati, A. A., \& Chandra, J. (2019). The influence of service quality,university image on studentsatisfaction and student loyalty. Benchmarking: An International Journal, 26(5), 1533-1549. http://doi. org/10.1108/BIJ-07-2018-0212

Damaris, A., Surip, N., \& Setyadi, A. (2019). Analysis Service on Student Satisfaction with Motivation as Moderating Variable. International Journal of Economics and Business Administration, 7(2), 118-130.

Hair, J. F., Hult, G. T. M., Ringle, C. M., \& Sarstedt, M. (2017). A primer on partial least squares structural equation modeling (PLS-SEM) (2 $2^{\text {nd }}$ ed.). Los Angeles, CA: Sage Publications, Inc.

Hasan, H. F. A., Ilias, A., Rahman, R. A., \& Razak, M. Z. A. (2008). Service quality and student satisfaction: A case study at private higher education institutions. International Business Research, 1(3), 163-175.

Iswara, W., \& Pratomo, L. A. (2018). The Influence of Higher Education Service Quality on Student Satisfaction and Loyalty. Journal of Economics and Business Research, 10(3), 174-188.

Latif, K. F., Latif, I., Sahibzada, U. F., \& Ullah, M. (2017). In search of quality: measuring Higher Education Service Quality(HiEduQual). Total Quality Management \& Business Excellence, 30(7-8), 768-791. http://doi.org/10.1080/1478336 3.2017 .1338133

Lukić, V. R., \& Lukić, N. (2018). Assessment of student satisfaction model: Evidence of Western Balkans. Total Quality Management \& Business Excellence, 1-13. http://doi.org/10.10 80/14783363.2018.1489227

Mohamad, M., \& Awang, Z. (2009). Building Corporate Image and Securing Student Loyalty in the Malaysian Higher Learning Industry. The Journal of International Management Studies, 4(1), 30-40.

Muhammad, N., Kakakhel, S. J., \& Shah, F. A. (2018). Effect of Service Quality on Customers Satisfaction: An Application of HEdPERF Model. Review of Economics and Development Studies, 4(2), 165-177. 
Nguyen, D. T., Pham, V. T., Tran, D. M., \& Pham, D. B. T. (2020). Impact of Service Quality, Customer Satisfaction and Switching Costs on Customer Loyalty. Journal of Asian Finance, Economics and Business, 7(8), 395-405. http://doi. org/10.13106/jafeb.2020.vol7.no8.395

Paul, R., \& Pradhan, S. (2019). Achieving Student Satisfaction and Student Loyalty in Higher Education: A Focus on Service Value Dimensions. Services Marketing Quarterly, 40(3), 245-268. http://doi.org/10.1080/15332969.2019.1630177

Rahman, S. M. M., Mia, M. S., Ahmed, F., Thongrak, S., \& Kiatpathomchai, S. (2020) Assessing Students' Satisfaction in Public Universities in Bangladesh: An Empirical Study. Journal of Asian Finance, Economics and Business, 7(8), 323332. http://doi.org/10.13106/jafeb.2020.vol7.no8.323

Rain, R., Sinha, G., \& Sahney, S. (2011). Conceptualizing service quality in higher education. Asian Journal on Quality, 12(3), 296-314. http://doi.org/10.1108/15982681111187128

Sekaran, U., \& Bougie, R. (2016). Research Methods for Business A Skill-Building Approach (Seventh Edition ed.): John Wiley \& Sons.

Tabash, M. I., Albugami, M. A., Salim, M., \& Akhtar, A. (2019). Service Quality Dimensions of E-retailing of Islamic Banks and Its Impact on Customer Satisfaction: An Empirical Investigation of Kingdom of Saudi Arabia. Journal of Asian Finance, Economics and Business, 6(3), 225-234. http://doi. org/10.13106/jafeb.2019.vol6.no3.225
Thomas, E. H., \& Galambo, N. (2004). What satisfies students?: Mining Student-Opinion Data with Regression and Decision Tree Analysis. Research in Higher Education, 45(3), 251-269. http://doi.org/10.1023/B:RIHE.0000019589.79439.6e

Uddin, M., \& Ali, K. (2018). Impact of Service Quality (SQ) on Student Satisfaction: Empirical Evidence in the Higher Education Context of Emerging Economy. Journal of Islamic Social Sciences and Humanities, 16, 31-67.

Ushantha, A. C., \& Kumara, P. A. P. S. (2016). A Quest for Service Quality in Higher Education:Empirical Evidence from Sri Lanka. Services Marketing Quarterly, 37(2), 98-108. http://doi. org/10.1080/15332969.2016.1154731

Yeo, R. K. (2008). Brewing service quality in higher education: Characteristics of ingredients that makeup the recipe. Quality Assurance in Education, 16(3), 266-286. http://doi. org/10.1108/09684880810886277

Yeo, R. K., \& Li, J. (2014). Beyond SERVQUAL: The competitive forces of higher education in Singapore. Total Quality Management \& Business Excellence, 25(1-2), 95-123. http:// doi.org/10.1080/14783363.2011.637802

Yusof, N., Zaini, B. J., \& Mansor, R. (2019). A Study on Factors Influencing Student Loyalty Towards Higher Learning Institution. IN: AIP Conference Proceedings 2138. https://doi. org/10.1063/1.5121037

Zeithaml,V.A.,Berry,L.L.,\&Parasuraman,A.(1996). TheBehavioral Consequences of Service Quality. Journal of Marketing, 60(2), 31-46. http://doi.org/10.1177/002224299606000203 